\title{
A AVENTURA FABULOSA EM \\ O ANO DE 1993: MEMÓRIAS DO PORVIR*
}

THE FABLED ADVENTURE OF

O ANO DE 1993: MEMORIES OF THE WORLD TO COME

\section{Tania Mara Antonietti Lopes}

Universidade Estadual Paulista

Araraquara - SP

\begin{abstract}
Resumo
A partir da leitura de $O$ ano de 1993 (1975), de José Saramago - cuja interpretação parte do surrealismo e dos romances distópicos de ficção científica -, propomos uma análise que nos permita relacionar esse livro também à epopeia, uma vez que, embora não haja um herói específico, açóes gloriosas ou feitos memoráveis (entre outros elementos que caracterizam o gênero), entrevemos no poema narrado uma sucessão de eventos extraordinários que provocam surpresa e maravilha - apesar de grande desilusão em determinados momentos - na medida em que relatam a aventura do homem (herói e carrasco) na terra. A partir do exercício interpretativo que propomos, esperamos confirmar a nossa hipótese referente à circularidade de traços insólitos que caracterizam a maior parte da ficção saramaguiana, presentes desde o período formativo do autor, como será demonstrado aqui.
\end{abstract}

Palavras-chave: $O$ ano de 1993, José Saramago, surrealismo, distopia.

\section{Abstract}

Based on our reading of $O$ ano de 1993 (1975), by José Saramago, and using an interpretative framework stemming from Surrealism and dystopian science fiction novels, we propose an analysis that allows us to draw parallels between this book and the epic tradition, given that, despite the lack of a single epic hero, or glorious actions or memorable feats (among other typical elements of the genre), it is still possible to observe in the narrated poem a chain of extraordinary events that provoke surprise and wonder - albeit great disillusionment in certain moments - as they relate the adventure

\section{Resumen}

En nuestra lectura de $O$ ano de 1993 (1975), de José Saramago, una interpretación que parte del surrealismo y de los romances distópicos de cienciaficción, proponemos un análisis que nos permita relacionar este libro también con la epopeya, una vez que, aunque no haya un héroe específico, acciones gloriosas o hechos memorables, entre otros elementos que caracterizan el género, es posible ver en la narración del poema una sucesión de eventos extraordinarios que provocan sorpresa y maravilla, a pesar de una grande desilusión en determinados momentos, en la medida

\footnotetext{
* Este artigo foi elaborado com o auxílio da bolsa de Pós-Doutorado da FAPESP (\#2013/09928-6). 
of man (as hero and hangman) on Earth. Through the interpretative exercise we propose, we hope to demonstrate our hypothesis about the circularity of extraordinary traits that characterize most of Saramago's fiction, present since the author's formative period.

Keywords: $O$ ano de 1993, José Saramago, surrealism, dystopia. que relatan la aventura del hombre, héroe y verdugo, en la tierra. Con el ejercicio interpretativo que proponemos, esperamos confirmar nuestra hipótesis referente a las circularidad de rasgos insólitos que caracterizan la mayor parte de la ficción de Saramago, presentes desde el periodo formativo del autor, como será demostrado aquí.

Palabras claves: $O$ ano de 1993, José Saramago, surrealismo, distopia.

O ano de $1993^{1}$, tratado por José Saramago como um "poema longo", foi publicado em 1975. Trata-se de um explícito diálogo com a ficção, que torna possível a relação com outras formas literárias e com o mundo representado, possibilitando, com isso, o nascimento de uma forma híbrida, claramente refletida na produção posterior do autor português. Encontramos nesse extenso poema uma disposição imagética e uma linguagem que remetem à estética surrealista. Será um dos caminhos para a nossa leitura. $\mathrm{O}$ outro diz respeito à clara referência a 1984 (George Orwell, 1949) e a Fahrenheit 451 (Ray Bradbury, 1953), fato que insere o poema na vertente das narrativas não só de ficção científica, mas, principalmente, nas distopias.

Em termos estruturais, $O$ ano de 1993 é um relato dividido em trinta segmentos. Inserido numa dimensão pictórica, o primeiro segmento tem início com uma alusão direta a Salvador Dalí:

As pessoas estão sentadas numa paisagem de Dalí com as sombras muito recortadas por causa de um sol que diremos parado

Quando o sol se move como acontece fora das pinturas a nitidez é menor e a luz sabe muito menos o seu lugar

Não importa que Dalí tivesse sido tão mau pintor se pintou a imagem necessária para os dias de 1993 (SARAMAGO, 2007: 7, grifos nossos)

\footnotetext{
${ }^{1}$ Nossa edição, publicada pela Companhia das Letras, é de 2007.
} 
A alusão nos remete a uma paisagem marcadamente surrealista, em que personagens sem nome protagonizam uma história que poderia acontecer, na qual impera o imaginário, a transgressão dos limites do real e o onírico. Nas três estrofes percebemos o primeiro movimento da efabulaçáo - são três -, em que se expressa um mundo parado, estático como numa parede branca. $\mathrm{O}$ andamento das estrofes nos dará a impressão de um mundo sem esperança, onde o sol parece estar imóvel como num quadro de Dalí.

Compreendemos essa afirmação sobre o pintor surrealista como uma reflexão que anuncia o futuro ficcionista Saramago, que contraria suas próprias afirmaçóes, uma vez que a pintura de Salvador Dalí é considerada de extraordinária perfeição formal. Mas no livro não se trata de um quadro, pois

Uma das pessoas vai riscando no chão uns traços enigmáticos que tanto podem ser um retrato como uma declaraçáo de amor ou a palavra que faltasse inventar

Vê-se agora que o sol afinal não estava parado e portanto a paisagem é muito menos daliniana do que ficou dito na primeira linha (SARAMAGO, 2007: 9)

Acima, uma vez que o sol não está parado, saímos do pictórico para adentrar um mundo estranho, apresentado através de segmentos que se distanciam por intervalos temporais e visuais, cujos versos são como instruçôes que conferem ao conjunto o caráter doentio, de cunho surrealista. A relação do poema com essa estética abriu para o autor português um caminho de grande êxito literário para a obra posterior, graças à proliferação imagética responsável pela valorização do imaginário, conduzindo-a (a obra) para o maravilhoso (COSTA, 1997: 223).

O que nos interessa é que o poema emerge como uma "constelação" de imagens. É dessa perspectiva que pensamos $O$ ano de 1993 inserido na estética surrealista. Ainda no primeiro segmento, "Uma sombra estreita e comprida toca no dedo que risca a poeira do chão e começa a devorá-lo" (SARAMAGO, 2007: 9-10). "Passa-se às imagens 'invividas', que a vida não prepara, mas que o poeta cria. E, assim como num laboratório surrealista, assiste-se a uma abertura da linguagem" (FELÍCIO, 2008: 878). Nesse sentido, percebemos que $O$ ano de 1993 se aproxima do verossímil pelas imagens que se referem à realidade e à possibilidade do porvir. Poderíamos pensar em uma metalinguagem, inclusive: a poesia num jogo lúdico com a ficção e o que essa ficção propõe. Na paisagem insólita, chama-nos a atenção a presença de uma sombra sorrateira, a consumir silenciosamente a personagem que 
risca o chão e não percebe que é devorada. A alusão a essa sombra retornará nas últimas estrofes do segmento 30 e a sua presença pode ser significativa.

$\mathrm{O} 2^{\circ}$ segmento nos apresenta a cidade doente de peste, cujos habitantes foram retirados por uma ordem que ninguém ouviu: "Alguma coisa podia talvez suceder no mundo antes do triunfo final da peste nem que fosse uma peste maior" (SARAMAGO, 2007: 10-11). A peste descrita no verso, em sua abstração kafkiana, antecipa em vinte anos a cidade contaminada de Ensaio sobre a cegueira (1995), além de indubitavelmente conter um traço bíblico, enquanto no $3^{\circ}$ segmento, "O elevador deixou de funcionar não se sabe quando", num alto edifício, remetendo-nos às imagens que serão retomadas em "Coisas", conto de Objecto Quase (1978). Até certo ponto, as estrofes desse segmento narram a situação disfuncional da cidade, para complementar cenas de imobilidade com o "mais longo gemido da história do mundo", emitido há tempos por uma mulher. Nesse segmento como um todo, o horror surrealista atinge seu auge e, novamente, as estrofes nos projetam para a atmosfera angustiante de Ensaio sobre a cegueira. Primeiro, pela presença de uma personagem feminina e, segundo, pela ideia - constante desde as crônicas - do "olhar com atenção" para o mundo onde vivemos. Nesse aspecto, remetemo-nos aos surrealistas, para quem "[o] mundo das realidades visíveis é o símbolo de um mundo invisível” (FELÍCIO, 2008: 885). É possível depreender das imagens presentes no segmento 3 o caráter grotesco que desarticula o real, tornando-o surreal, o que possibilita o intercâmbio entre os fenômenos da representaçáo e do mundo exterior, promovendo a fusão da realidade e surrealidade.

Assim, a manifestação do surrealismo se expressa dessa forma para nos conduzir, no $4^{\circ}$ segmento, ao hiper-realismo das cenas de um interrogatório que dura quinze dias, remetendo-nos aos momentos de opressão que deixam rastros de horror: "Há quinze dias que o homem não dorme nem dormirá enquanto o ordenador não disser náo preciso de mais ou o médico não preciso de tanto" (SARAMAGO, 2007: 8-19). A cidade descrita em $O$ ano de 1993 encontra-se sob um regime despótico, ocupada por invasores que submetem seus habitantes a todo tipo de humilhação e privação.

No $5^{\circ}$ segmento, entretanto, "A cidade que os homens deixaram de habitar agora está sitiada por eles", e nenhuma explicação por parte do narrador é oferecida. "Na cidade apenas vivem os lobos / Deste modo se tendo invertido a ordem natural das coisas estão os homens fora e os lobos dentro" (SARAMAGO, 2007: 22). Não há transição entre a saída dos homens e a ocupação pelos lobos, ou ela náo é relatada. A humanidade agora mantém-se fora dos limites urbanos, enquanto, no segmento 6 , por meio do conhecimento da obra vindoura de Saramago, entendemos que a simbologia de $O$ ano de 1993 nos liga à esfera que envolverá a futura cidade dos cegos. 
As imagens dessa cidade, cuja praça expóe "cinquenta estátuas de cada lado incrivelmente brancas", que parecem se mover conforme "os jogos das luzes e das sombras alternadas" (SARAMAGO, 2007: 27), remetem-nos à arte metafísica de De Chirico. A utilização do registro surreal-maravilhoso é o que permanecerá na ficção posterior de José Saramago. A estética surrealista se constitui nesse texto pelas imagens e pela mecânica associativa entre elas, muito bem manejadas pelo autor. A sequência entre as imagens se dá pela escrita pungente e rápida. Assim, do segmento 7 ao 13, percebemos uma aproximação maior de fatos considerados inverossímeis, mas que, de modo insólito, relacionam-se a eventos caracterizados por violência: como o comandante das tropas de ocupação ter um feiticeiro que intervém quando se deseja "usar o chicote". Por meio de poderes ocultos, o mágico "reduz a cidade ao tamanho de um corpo humano" (SARAMAGO, 2007: 30). A importância de uma percepção imagética estrutura o texto de Saramago. Para os surrealistas, "o leitor é transportado para um universo de imagens, fora da lógica cartesiana habitual e de um mundo regido pela causa eficiente. É um mundo de símbolos e desejos inconscientes que manifestam a sombra do ser humano" (FELÍCIO, 2008: 892). Assim, apresentados metaforicamente, observamos, nas cenas de chicoteamento, espaços ocupados pela violência. Não se trata de exprimir a realidade transfigurando-a, mas de ultrapassá-la, alcançando uma realidade invisível aos olhos comuns, pois as "associaçôes de imagens as mais inesperadas revelam-nos a verdadeira realidade que é imaginária” (ELÍCIO, 2008: 893).

A proliferação imagética significará uma mobilização da obra de Saramago em direção ao maravilhoso, confirmando a valorização do imaginário em sua escrita. Desse modo, as imagens do segmento 8 se estabelecem como o ponto alto da presença surrealista no poema como um todo: por sua natureza extremamente insólita e grotesca, justificando aqui a transcrição quase íntegra do segmento.

Está determinado que hoje se travará uma grande batalha e náo obstante o número de mortos previsto assim se fará [...]

Apenas porque o ódio entrou enfim no corpo das mulheres

Será visto que estando mortos os homens Perseguidos os perseguidores hão-de violá-las conforme mandam as imemoriais regras da guerra [...] 
Por isso a longa fileira das mulheres deitadas espera com indiferença que é simulada a penetração dos perseguidores

[...]

Silenciosamente suportam o assalto e abrem os braços enquanto a raiva corre pelo sangue para o centro do corpo

Há um derradeiro momento em que o perseguidor ainda poderia retirar-se

Mas logo é tarde e no exacto instante em Que o espasmo militarmente iria deflagrar

Com um estalo seco e definitivo os dentes que o ódio fizera nascer nas vulvas frenéticas

Cortam cerce os pénis do exército perseguidor que as vaginas cospem para fora com o mesmo desprezo com que os homens perseguidos haviam sido degolados

Uma só mulher porém enquanto as outras celebram a justa vitória retira suavemente o membro amputado que ainda tivera tempo de ejacular

E levantada comprime o sexo com as mãos e afasta-se pela planície na direcção das montanhas (SARAMAGO, 2007: 33-36)

Trata-se de um "episódio" cuja imagética confirma a ideia dos surrealistas em relação à linguagem, isto é, a imagem ressoa no nível da própria linguagem. Representando as imagens vívidas, pensamos aqui no ódio das mulheres ao ocupador: depois de se entregarem a ele com aparente descaso, ocorre uma quebra de expectativa e surpresa (do leitor) quando "as vulvas frenéticas" cortam os pênis e os cospem fora com desprezo. Retomando a ideia surrealista de que "o imaginário é sempre um além de suas imagens, um pouco mais do que elas mesmas" (FELÍCIO, 2007: 879), parece-nos que o $8^{\circ}$ segmento comprova isso, devido a um elemento que nos surpreende, e que se constitui de perverso erotismo: quando uma mulher, após a ejaculação, retira de sua vagina o membro amputado e se afasta. 
Dando prosseguimento, tanto às imagens quanto às situaçóes surreais, no segmento 9 ficamos sabendo que "Todas as noites três vezes se faz a contagem dos habitantes que foram autorizados a viver na cidade" (SARAMAGO, 2007: 37). Essa contagem é feita por ratos, cobras e aranhas, respectivamente, $\mathrm{e}$ "Todas as noites enlouquecem dois ou três habitantes da cidade" (SARAMAGO, 2007: 40), dando continuidade ao horror, precipitando essa imagem na esfera surreal para desviar a percepção estética da realidade costumeira, como pressupunham os surrealistas. O relato desses fatos nos vai dando ideia de como vivem os homens no sistema sombrio e distópico dessa sociedade, pois no $10^{\circ}$ segmento o narrador descreverá como certos homens se adaptaram para sobreviver à escuridáo do mundo representado: "Certos homens embora não adaptados morfologicamente passaram a viver debaixo do cháo" (SARAMAGO, 2007: 41-42), e no segmento 11 veremos confirmada a afinidade de José Saramago com os romances distópicos de ficção científica, já confessada em suas crônicas ${ }^{2}$. A partir desse ponto, percebemos o hibridismo que se articula no desenvolvimento da narrativa, uma vez que os traços surrealistas serão essenciais na tessitura do tema, assim como a presença do mito e do maravilhoso. Desse modo, após as imagens que observamos nos segmentos anteriores, os habitantes presenciarão o surgimento de uma grande esfera que justificará a transcrição de quase todo o segmento, dada a narrativa que oferece.

Foram requisitados todos os termómetros da cidade e proibida sob pena de morte a sua posse [...]

Graças ao desaparecimento dos termómetros as crianças puderam muitas pela primeira vez sentir a frescura das mãos do pai ou da mãe sobre a testa quente

\section{Alguma coisa portanto parecia ter sido ganha}

Até ao dia em que a população compreendeu o fim a que se destinava o mercúrio retirado dos termómetros e todo o outro existente noutros lugares

As pessoas que moravam na periferia da cidade e por isso podiam ver o sol

\footnotetext{
2 "Um azul para Marte"; "O planeta dos Horrores" (Deste Mundo e do Outro).
} 
Acreditaram enfim que o mundo ia acabar

porque ao lado do velho sol alaranjado subia uma esfera fria e negra com reflexos de cinza

Só essas pessoas assistiram ao primeiro aparecimento do grande olho que iria passar a vigiar a cidade [...]

Mal o sol verdadeiro subiu um pouco no horizonte a esfera de mercúrio dividiu-se em duas em quatro em oito em dezasseis em trinta e duas em centenas de esferas que se espalharam por toda a parte

Deslocavam-se no ar silenciosamente e continuavam a dividir-se até que houve tantas esferas quantos os habitantes da cidade

Fora instituído o olho de vigilância individual que não dorme nunca (SARAMAGO, 2007: 45-48, grifos nossos)

Essa “cena” é inteiramente referente a 1984, desde a menção a habitantes de lugares periféricos à presença do grande olho do poder. A linhagem "futurante-distópica" foi inaugurada por Huxley (Brave New World, 1932). Nessas obras da literatura inglesa, e em $O$ ano de 1993, "o assunto tratado traduz as peculiaridades de uma distopia futura e a problematização metafórica e crítica do mundo que lhe deu origem" (COSTA, 1997: 215), ou seja, o mundo em que tem lugar a escrita sobre os livros que lemos. No segmento 11 , a presença do olho vigilante elabora um diagrama amplo de controle político, se assim podemos dizer, determinado pela organização totalitária, assim como ocorre nas distopias: o "grande olho" representa o "aleph borgesiano que num mundo de surrealismo português, povoado por realidades pequenas, pequenos animais nojentos, se cindem ameboidamente em olhos individuais, vigiadores de cada homem" (PICCHIO, 2000: 359). Em 1984, Orwell apresenta ao leitor uma sociedade totalitária onde cada indivíduo é rigidamente controlado fisicamente e ideologicamente, fato que podemos deduzir da atmosfera de $O$ ano de 1993, uma vez que as esferas vigilantes se deslocavam no ar, silenciosamente.

Sobre a leitura surrealista do poema, chama-nos a atenção um fato que se opóe ao clima angustiante da descrição das esferas, relacionado ao comportamento entre as personagens dessa sociedade, quando o narrador afirma que, graças ao sumiço dos termômetros, as crianças puderam sentir o 
contato das mãos de seus pais, muitas pela primeira vez e que, por isso, "Alguma coisa portanto parecia ter sido ganha". Parece-nos que, nesse momento, o narrador aponta para a possibilidade de esperança baseada num suposto afeto refletido. É o primeiro momento, desde o início do livro, que vislumbramos algo positivo, digamos assim, em todo o relato, e colocado de um modo poético, próximo do encantamento, considerando as circunstâncias descritas - porque, longe de terminar o horror, trata-se apenas de uma fagulha na escuridáo que se aproxima, uma vez que, na cidade distópica e surreal de $O$ ano de 1993 , vemos alegorizadas as possibilidades de terror em um mundo dominado pela violência e pela opressão, cujo clima de pesadelo coletivo resulta, no segmento 12 , na rebelião dos animais domésticos, cuja primeira vítima foi a mulher do governador. Trata-se de uma referência, mais aterrorizante, ao Orwell de $A$ revolução dos bichos (1945). Os versos mostram que os animais domesticados são tomados pelo ódio aos seus donos, e se vingam, enquanto o $13^{\circ}$ segmento nos projeta mais uma vez para "Coisas", intensificando ainda mais a descrição do sistema de repressão e controle que se desenvolve num crescendo na fábula surreal: "No lugar das antigas cadeias construíram-se edifícios de seis andares todos de vidro transparente" (SARAMAGO, 2007: 51-53).

Até aqui, a focalização se ateve à descrição do cotidiano na cidade ocupada. A partir do $14^{\circ}$ segmento, o narrador, ainda pela focalização externa, apresentará a descrição de como se organiza a tribo e das misérias sofridas até seu regresso triunfal à cidade. Veremos exacerbar-se o clima de violência, desencadeado nos segmentos anteriores, culminando em imagens sanguinolentas, mas misturadas a outras que amenizam o horror e conduzem o relato para o maravilhoso, preconizado pelo surrealismo, que visava "atingir e exprimir a profundidade da relação entre o homem e o mundo, numa visão surracional e surreal, respectivamente. É através do fantástico e do maravilhoso que chegam à verdadeira realidade" (FELÍCIO, 2007: 879).

Aliados ao maravilhoso, que observaremos daqui em diante, perceberemos que os acontecimentos transcendem para o mito, também presente na ficção saramaguiana. É importante notar que, do primeiro segmento até o $13^{\circ}$, as descriçóes são estáticas, sem movimento. A partir de agora, o relato apresentará mais ação. No segmento 14, o narrador nos inteira de que o acampamento da tribo é defendido por dois casais, "Estão sentados de pernas cruzadas atentos a todas as sombras e gritam quando há perigo". Foi decidido que todas as manhãs "o homem do norte e a mulher do sul o homem do oriente e a mulher do ocidente" juntariam "os sexos" sob os olhos da tribo reunida: "Enquanto a união dura cantam em redor" (SARAMAGO, 2007: 55).

É nítida a diferença, no que diz respeito à empatia, entre os indivíduos da tribo e os habitantes da cidade. Os primeiros náo perderam a humanidade, 
enquanto os ocupadores praticam atrocidades visando repressão e controle, e os remanescentes assistem impassíveis às torturas dos presos em suas celas transparentes. Perceberemos, daqui em diante, que o narrador estabelece uma oposiçáo entre a degeneração urbana (anterior à ocupação da cidade pelo exército) e a tribo, cuja visão aparece idealizada por meio dos melhores traços humanos, como a solidariedade, a fraternidade, a compaixão e o espírito coletivo. Toda essa idealização se expressa também na relação da tribo com os elementos naturais. Pela primeira vez, no segmento 15, o narrador se coloca no relato: "Porém não devemos esquecer o mar que é o princípio e o fim de todas as coisas". Essa interferência, resgatando a imagem do mar (táo presente na narrativa portuguesa), soa confiante num futuro melhor, e se apresenta em tom profético:

É certo que nos dias de 1993 poucas pessoas ainda serão capazes de imaginar os primeiros tempos do mundo $[\ldots]$

O mar subitamente acalma e um lento murmúrio de um lado e do outro reconsidera os factos

Que em verdade náo excluem uma maré renovada e uma coragem à medida do tempo que passou desde a primeira de todas as mortes (SARAMAGO, 2007: 57-60)

Parece-nos que o segmento 15 tem como função preparar o leitor para a reconquista da cidade ocupada pelos homens da tribo. Esse relato possibilita a inferência de que, quando os homens alcançaram um limite insuportável de sofrimento, houve a necessidade de uma revolução realizada sem armas de fogo por parte dos oprimidos. Antes de efetuar, de fato, um movimento de ação que tomará a fábula até o final, há uma pausa, no segmento 16:

Mas foi de noite na negrura aflita da caverna lá onde só o olho vermelho das brasas tinha pena dos homens [...]

Que subitamente um homem descobriu que não sabia ler (SARAMAGO, 2007: 61-62)

Pensamos as estrofes acima como uma suspensão temporária no movimento do poema, dando-nos a ideia do eterno retorno associada ao 
primitivismo característico do tempo ainda sem a escrita. Recuperamos aqui o aspecto revolucionário do artista surrealista que, para concretizar a lógica do novo, do inusitado e do desconhecido, propóe uma poesia que transcende o valor social, "na medida em que o pensador-poeta remonta aos arquétipos do inconsciente coletivo [...]" (FELÍCIO, 2007: 884). Nesse aspecto, a interpretação surrealista de $O$ ano de 1993 corresponde aos elementos estéticos do tecido narrativo, como, por exemplo, a tomada de consciência coletiva. Mais do que uma suspensão, ocorre uma quebra na sequência narrativa estabelecida até o segmento 14. A continuidade será retomada apenas no segmento 18 . No $17^{\circ}$, mais uma vez seremos reportados a imagens de horror e perversidade humana. Esse segmento caracteriza-se pela aproximação ao romance distópico de Ray Bradbury, Fahrenheit 451, no qual aqueles que são suspeitos de contrariar as leis são perseguidos por cães-robôs, modificados para serem infalíveis na captura e destruição daqueles que se opunham à ordem estabelecida. No poema de José Saramago,

Todos os animais do jardim zoológico foram paralisados por acção de misturas químicas nunca antes vistas $[\ldots]$

Desta maneira tornados pele massa muscular e esqueleto foram os animais providos de poderosos mecanismos internos ligados aos ossos por circuitos electrónicos que não podiam errar [...]

Entáo abriram-se as portas da cidade e os animais saíram a destruir os homens (SARAMAGO, 2007: 65-66)

Concentrado no avanço da tribo em direção à cidade, o segmento 18 apresenta uma cena do fogo sendo transportado por quatro mulheres que "gritaram de desprezo" ao vê-lo apagado.

Assim começou aquela primeira noite de escuridão com todo o bando amassado numa nódoa de sombra sob o pálido e distante luzeiro das estrelas [...]

Uma criança disse que vira afastar-se na direç̧áo do poente um homem da tribo e que isso fora depois de o lume se apagar [...] 
Então sobre o disco vermelho viram os homens e as mulheres sobreviventes um ponto negro que aumentava e julgaram que o próprio sol ia apagar-se

Até ao momento em que distinguiram o homem que corria para eles o companheiro que os deixara duas noites antes e que nesse homem havia também um ponto luminoso

Uma labareda que vinha do braço levantado e que era a própria mão ardendo da luz do sol roubada (SARAMAGO, 2007: 70-73)

Trata-se de uma nítida alusão a Prometeu, corroborando o que tínhamos afirmado sobre a presença do mito inserido no relato. O homem que trazia na mão a "luz do sol roubada" se configura, para nós, como o símbolo antecipado da vitória da tribo, embora sejam relatados, no segmento 19, fatos que antecipam a atmosfera sombria e angustiante de "Coisas", onde os habitantes tinham suas mãos marcadas com letras, para designar hierarquia. Os habitantes foram numerados de 1 a $57229^{3}$ e ninguém reconhecia autoridade ao que tivesse um número maior que o seu4, "o que explica que o 57229 comesse com os cães e tivesse de masturbar-se porque nenhuma mulher queria dormir com ele" (SARAMAGO, 2007: 77). Os habitantes de 1 a 9 se vestiam como os ocupantes, visto que se consideravam chefes da cidade ${ }^{5}$, enquanto o primeiro ${ }^{6}$ mandou fazer "um aro de ouro que suspendia sobre a testa como sinal de poder e autoridade e hoje basta este sinal para que todas as cabeças se curvem a partir de 2" (SARAMAGO, 2007: 77). Porém, apenas o computador sabe que aqueles números são provisórios e se apagarão dentro de vinte e quatro horas, para reaparecerem em ordem inversa, evidenciando, com isso, a ridicularização do poder e da hierarquia.

O posicionamento crítico do poeta se aproxima do que os surrealistas consideram sobre a imaginaçâo dinâmica: "bastante viva no sujeito [...] sofre e age nos poemas. Sendo libertadora, como já o admitiam os surrealistas, a imaginação dinâmica é uma realidade primeira, porque ontológica" (FELÍCIO, 2007: 889). Assim, entendemos o duplo movimento do livro - do sombrio

\footnotetext{
${ }^{3}$ Em "Coisas", eram marcados de A a Z.

${ }^{4}$ No conto, a letra precedente concedia o direito de consumo de objetos melhores ao cidadão utente.

${ }^{5}$ Em "Coisas", essa ideia corresponde aos que eram marcados com a letra C.

${ }^{6}$ Cidadáos marcados com as letras A e B, no conto, ocupavam o governo.
} 
ao esperançoso - como um processo que se afina com a imaginaçáo dinâmica postulada pelo surrealismo, uma vez que existe na narrativa de $O$ ano de 1993 a dialética da luz e da sombra, a noite e o dia, o baixo e o alto. A imaginação dinâmica, nesse caso, uniria as imagens que se opóem para complementar o todo de uma história que pode representar a do homem, fazendo-nos compreender o texto, principalmente quando há uma ação profunda, como algo que se eleva.

Para além de poesia e enredo, o segmento 20 confirma o que mencionamos sobre o texto de Saramago se apresentar também como uma epopeia. Nele percebemos que se desenvolve uma narrativa continente da ideia de eterno retorno, característica dos mitos cosmogônicos, mas que aqui apresenta uma "sequência" inversa, porque a luta pela sobrevivência da tribo adquire impulso a partir de uma atmosfera apocalíptica. Na continuaçáo do segmento 20, descrevendo ainda a deploração da tribo, vemos o surgimento de uma árvore mágica que envolve "o homem e a mulher que se tinham escolhido para sempre afastarem-se na direcção de uma floresta que fechava o céu" (SARAMAGO, 2007: 80). A partir desse momento, assistimos à fusão do maravilhoso com o discurso crítico do autor português. "Então abraçados o homem e a mulher sem uma palavra suplicaram" (SARAMAGO, 2007: 81)

A ressonância bíblica das estrofes confere o caráter profetizante do segmento, exigindo, assim, uma tomada de consciência coletiva, correspondendo à fundação de uma nova linguagem e, paradoxalmente, a uma nova mitologia, como indicam os segmentos 21 e 22 , em que vemos esses dois elementos - linguagem e mitologia - de acordo com os homens e com a natureza. Assim, por meio do regresso aos cultos primitivos, visto que a tribo perdera as palavras indispensáveis para expressar a subjetividade, "Não admira que fosse preciso reaprender a linguagem simplificada da fome e do frio [...] Para começar o outra vez doloroso nascimento duma primeira palavra" (SARAMAGO, 2007: 85-88).

No segmento 22 notamos a fundação de uma nova mitologia, pois "os antigos deuses haviam morrido"; então, "os homens descobriram outros" que sempre existiram, mas estavam encobertos "pela sua não necessidade". Nesse processo de substituição dos deuses, chama-nos a atençáo as duas últimas estrofes, quando "deus só ficou o rio".

Definitivamente deus só ficou o rio porque os homens vão mergulhar nele as mãos e o rosto e têm estrelas nos olhos quando se levantam

Enquanto as águas por sua vez transportam ao céu e ao sol se o há a turvidão salgada das lágrimas e do suor (SARAMAGO, 2007: 89-91) 
A imagem dos homens, primeiro se curvando para lavar as mãos e o rosto, para depois olhar para o alto, remete-nos imediatamente à crônica "Cada vez mais sós" , em que o narrador nos instiga a olhar para o céu, mas com a consciência de que somos responsáveis pela terra, e pela humanidade como um todo. E se substituirmos a imagem do rio pelo mar, na última estrofe, é forçosa a referência ao "Mar Português". ${ }^{8}$ Nesse aspecto, acreditamos que a sensibilidade do escritor se origina a partir da associação do discurso maravilhoso com o sentido da mensagem da obra literária, elaborada num momento em que o 25 de abril era visto de uma perspectiva desiludida. Assim, a busca de uma religiosidade por parte da tribo se contrapóe com as determinaçôes do ocupante, cuja visão em relaçáo à magia adquire contornos perversos. No segmento 23, por exemplo, a capacidade maquiavélica e cruel do computador que controla a cidade mostra-se agora consumidora de carne humana, porque a eletrônica não basta.

Não apenas a visão sobre a magia, mas também o ponto de vista sobre os valores religiosos e espirituais do ocupante divergem da perspectiva dos membros da tribo. Mas o cérebro náo pode ser consumido por esse computador e, "sem que o inspector de serviço se apercebesse uma certa máo cortada metida na câmara apertava no oco dos dedos uma pasta acinzentada contendo algumas centenas de milhóes de neurónios" (SARAMAGO, 2007: 95). Esse detalhe possibilitará a salvação daqueles que nesse dia seriam eliminados. A partir de agora, uma nova utopia se instala no livro, substituindo a distopia presente desde o início da fábula. Assim, no segmento 24, tem início uma luta contra o ocupante, que persistirá durante o número bíblico de sete dias e sete noites: "Ao amanhecer do oitavo dia surgiram em campo raso e viram um leão imóvel de pé sobre as quatro patas" (SARAMAGO, 2007: 98-99).

No que diz respeito à circularidade das formas do insólito na ficção saramaguiana, no segmento 25 podemos observar a relação do texto com o realismo mágico, que aparecerá sobretudo em $A$ jangada de pedra (1986). No decurso da reconquista da cidade, há novamente uma pausa para mencionar que, embora há muito tempo não nascessem crianças, a tribo não perdera completamente a lembrança de "um mundo fértil". As tribos mais sedentárias redescobriram antigas "práticas mágicas" e nos campos cultivados "faziam correr mulheres menstruadas" que, nuas, "com sangue de vida e não de morte", corriam "deixando um rasto que os homens cobriam cuidadosamente de terra para que nem uma gota secasse o calor agora nocivo do sol” (SARAMAGO, 2007: 102). Nesse momento, notamos a reaparição da mulher que, no segmento 8 , separou-se de sua tribo. Recordemos que essa mulher foi a única que deixou

\footnotetext{
${ }^{7}$ Deste Mundo e do Outro (1997).

${ }^{8}$ Mensagem (2007).
} 
o pênis decepado ejacular em sua vagina. Chegou grávida, "quase no fim do tempo, e pediu que a deixassem ficar até parir".

Mas antes que a criança nascesse um homem escolhido da tribo uniu-se carnalmente à mulher grávida

E desta maneira tudo começou naquele lugar e não noutro com aquela gente e não outra apenas com o presente e o futuro não o passado

Alguns dias mais tarde nasceu uma criança e houve as melancólicas festas de então e todas as mulheres se declararam grávidas (SARAMAGO, 2007: 102-103)

A segunda e a terceira estrofes seriam uma referência direta ao romance A jangada de pedra-se não tivesse sido publicado após o poema-, que tem em sua epígrafe - Todo futuro es fabuloso - a ideia que corresponde à história que poderia ter sido, como afirmou tantas vezes os variados e variáveis narradores de José Saramago. Em seu romance, que consideramos como um exemplar de realismo mágico, todas as mulheres da Península Ibérica - quando não mais sendo Europa - engravidam. A projeção dessa ideia, entretanto, é mais otimista em sua conclusão futura quando atentamos para a última estrofe, que prenuncia a batalha sangrenta e definitiva, referida, no segmento 26, por versos com traços épicos em que percebemos valores claramente heroicos.

Entre o sopé da montanha e a primeira porta da cidade ficaram mortos muitos homens e mulheres $[\ldots]$

Derrubados sobre a terra com a boca aberta como se dissessem a pena de morrerem ou murmurando alguma coisa da memória recobrada por inteiro no momento de por inteiro se perder $[\ldots]$

Quando a primeira porta foi alcançada amontoaram-se os corpos uns sobre os outros e os vivos passaram sobre uma ponte de mortos que eram a escora e o arco e a macia e dolorosa calçada (SARAMAGO, 2007: 105-107) 
Nas estrofes supracitadas, o relato remete ao início da batalha, especificamente ao primeiro momento, em que percebemos a referência a um pensamento que persistirá nos romances futuros do escritor e que tem a ver com o valor imensurável da vida e do ser humano no mundo, expresso na fala da avó Josefa, ao dizer que o "mundo é táo bonito, e eu tenho tanta pena de morrer" (SARAMAGO, 1997: 27). Mas o andamento dos versos culmina com a imagem de terror provocada pela justaposição inusitada de contrários das últimas estrofes.

É este o preço da paz quando o amanhecer vem perto e o medo de morrer é esse mais humano de não viver bastante $[\ldots]$

Distante julgaríamos O ano de 1993 e contudo é tempo dele ainda $[\ldots]$

Ó eloquentemente diríamos ó se não fosse preferível que percorrêssemos nós esta praia manchada de sangue dizendo algumas e discretas palavras em voz baixa meus amigos (SARAMAGO, 2007: 109-111)

A interferência do narrador na tessitura dos versos promove o jogo entre ficção e realidade, mesmo que se trate de poesia. O segmento 28 se constitui por uma postura mais agressiva, uma vez que é impossível não apresentar resistência diante da violência. As cidades foram reconquistadas uma a uma e de todos os lugares chega gente. Até metade do segmento, é relatado o delírio preconizado pela libertação; no entanto, os fragmentos adquirem um tom reticente, próprio de José Saramago, como um aviso que afirma ser impossível apagar a experiência emocional e as imagens do tempo da opressão: "Porém muitas batalhas farão ainda mortos entre os que riem agora e choram não a morte para eles próxima, mas a alegria de estar vivo" (SARAMAGO, 2007: 114).

Se a advertência remete ao tempo da distopia que inicia o poema, logo este é substituído por um desejo utópico por parte do narrador, prefigurando a preocupação do autor com a insistência humana em cometer cegamente os mesmos erros. Acompanhando a grande transformação, o segmento 29 retoma o tom característico de versículos bíblicos e imagens que remetem outra vez ao maravilhoso. "Levantou-se entâo um grande vento que varreu de estrema a estrema entre o mar e a fronteira a terra dos homens" (SARAMAGO, 2007: 117). Os versos recordam passagens do Gênesis e ocupam apenas o 
início do segmento, pois veremos predominar as imagens que privilegiam uma natureza paradisíaca, mas terrena e primitiva, pois "da terra subitamente verde" após a chuva surgiu um "enorme arco-íris" que não desapareceu nem à noite (SARAMAGO, 2007: 119).

Aqui se retoma a lógica imaginária surrealista, em que se torna acessível o mistério e o espaço transcendental do maravilhoso, característicos da esfera do poético. Vemos o maravilhoso percorrer o cotidiano - como supunha o surrealismo -, o estranho e o surreal constituírem o real. Desse modo, o segmento 29 retoma, quase que inteiramente, o tom surrealista do começo do poema. Nesse universo poético, os eventos mais inverossímeis parecem incontestáveis. A atmosfera onírica tem sua lógica e a "surrealidade" domina o maravilhoso e a magia do encantamento. Graças ao imaginário que se constitui na obra, a imaginação representa "a experiência do novo, do risco e do maravilhoso, tão caros ao surrealismo" (FELÍCIO, 2007: 878). No entanto, toda essa situaçáo que versa o onírico e um suposto estado de graça que se manifesta no segmento 29 , dissolve-se no 30 , última parte do poema.

Uma vez mais os lugares conhecidos os lugares de solidão e de morte os centímetros quadrados de tortura as cores do sangue até à sua final cor de terra [...]

Uma vez mais tudo o que uma vez foi ou muitas vezes as pegadas de hoje na marca dos pés antigos uma vez mais a mão no gesto começado e interrompido e assim sucessivamente

Uma vez mais a ida e o regresso e agora a esperada fadiga entre duas altas montanhas num cháo de pedra onde a sombra de repente fica enquanto o corpo dissolve no ar $[\ldots]$

E uma criança objectiva se aproxima e estende as mãos para a sombra que fragilmente retém o contorno ainda mas não já o cheiro do corpo sumido [...]

Uma vez mais o impossível ficar ou a simples memória de ter sido

Consoante se conclui de nada haver debaixo da sombra que a criança levanta como uma pele esfolada (SARAMAGO, 2007: 123-125) 
No segmento conclusivo do poema, temos a retomada perturbadora do movimento que abre o livro, reportando-nos ao aspecto opressor e mais abrangente da cidade, dando a ideia inflexível de que a luta é contínua, sempre será, pois o "basta" que marca o inconformismo dos marginalizados e dos oprimidos, "quando a grande escuridão redobrou o medo mas náo mais" (SARAMAGO, 2007: 81, grifos nossos), é sobrepujado pelo resgate do tempo de opressão que a expressão "Uma vez mais" confere ao segmento, que recupera também a "sombra" presente na abertura do poema, instaurando a circularidade que futuramente será uma característica da obra de Saramago.

No primeiro segmento do poema, uma sombra devora silenciosamente uma pessoa que tentava riscar algo no chão. Aqui, uma criança estende as mãos para a sombra que retém o contorno de um corpo sumido - seria o mesmo corpo que riscava o chão? Parece-nos que, no final dessa fábula impossível, o poeta ainda não se convence da história que poderia ser, uma vez que sua voz se prende entre o espaço do "impossível ficar" e "a simples memória de ter sido" (seria essa a maldição do homem português?), concluindo, nesse momento da narração épica do poema, que nada há "debaixo da sombra que a criança levanta como uma pele esfolada". A conclusão do poema nos intriga pela perplexidade. Não haverá nada entre o pessimismo desolador que predomina no início da fábula e sua esperança final?

Certamente é um poema indicativo da trajetória de José Saramago no momento em que caminha para o que se conheceu posteriormente de sua criação literária. Em $O$ ano de 1993, o autor utiliza versos para compor micronarrativas que, embora possam se configurar de maneira independente, contêm informaçóes precisas que se ligam e complementam outras que se seguem. Daí optarmos por tratar cada capítulo por segmento. Para confirmar o discurso futurístico e distópico, observamos uma aproximação dos versículos bíblicos, com traços apocalípticos e proféticos em muitas passagens que compóem o poema. A mistura do efeito surrealista com o discurso ideológico presente nesse livro, sem dúvida nos permite observar a antecipação do realismo maravilhoso presente posteriormente na obra de José Saramago, o que nos permite considerar $O$ ano de 1993 como precursor da fusão entre a postura crítica de José Saramago e o livre fluxo do imaginário maravilhoso, característico de sua posterior produção romanesca. 
COSTA, Horácio. O ano de 1993. In: José Saramago: o período formativo. Lisboa: Caminho, 1997. p. 214-253.

FELÍCIO, Vera Lúcia G. Bachelard e o Surrealismo: no espaço-tempo ultradimensional do maravilhoso. In: GUINSBURG, J.; LEINER, S. (Orgs.). O Surrealismo. São Paulo: Perspectiva, 2008: 875-898.

HATHERLY, Ana. José Saramago: O ano de 1993. Colóquio/Letras, n.31, Maio, 1976, p.87-88.

PICCHIO, Luciana Stegagno. O futuro do passado: O ano de 1993, de José Saramago. Veredas, n. 3, Porto, 2000. p. 351-362.

SARAMAGO, José. Ensaio sobre a cegueira. São Paulo: Companhia das Letras, 1995. . Deste Mundo e do Outro. Crônicas. 4. ed. Lisboa: Caminho, 1997. . A jangada de pedra. São Paulo: Companhia das Letras, 2006. . O ano de 1993. São Paulo: Companhia das Letras, 2007.

Tania Mara Antonietti Lopes. Tem Mestrado (2007) e Doutorado (2011) em Estudos Literários pela Universidade Estadual Paulista Júlio de Mesquita Filho. PósDoutorado pela FCL-Unesp (Araraquara), com bolsa FAPESP (2016). Experiência nas seguintes áreas: Literatura Portuguesa e Ensino de Literatura, e seguintes linhas: Formas do Insólito Ficcional, Relaçóes entre Ficção e História, Imaginário, Literaturas de Língua Portuguesa, Romance Português Contemporâneo. Membro do Grupo de Estudos da Narrativa (GEN).

E-mail: tantoniettilopes@gmail.com 